\title{
PERSPECTIVES IN PEDIATRIC PATHOLOGY
}

\section{Necrotizing Enterocolitis of the New born: Pathogenetic Concepts in Perspective}

\author{
Wei Hsueh, ${ }^{1}$ Michael S. Caplan, ${ }^{2}$ Xiaodi Tan, ${ }^{1}$ William MacKendrick, ${ }^{2}$ \\ AND F. GonZALEZ-CRUSS, ${ }^{1 *}$ \\ 1Department of Pathology, Children's M emorial Hospital, Northwestern University M edical School, \\ Chicago, IL 60614, USA \\ ${ }^{2}$ Department of Pediatrics, Evanston Hospital, Northwestern University Medical School, Evanston, IL 60201, USA
}

Received J une 19, 1997; accepted August 15, 1997

\section{DEFINITION AND GENERAL CONSIDERATIONS}

Necrotizing enterocolitis (NEC) has a multifactorial etiology, an incompletely defined pathogenesis, and predominantly affects neonates with severe, necrotizing injury to the intestine. Because the underlying clinical circumstances are not uniform, NEC may represent a syndrome, with common findings and a variety of etiologies. The uniform morphology of the well-established intestinal lesions, representing a latestageresponse, is consistent with a common pathogenesis. Discrepant etiologies are possible. Necrosis of the intestine can occur at any age following the sudden, complete occlusion of the blood supply to the bowel. In the newborn, thromboemboli secondary to the use of intravascular catheters may cause bowel infarction. However, since neonatal NEC cannot be traced to thromboemboli, it is considered nosologically distinct from bowel infarction in older patients. Therefore, in the following discussion NEC is understood to exclude cases of bowel infarction associated with thromboembolic lesions.

NEC remains a leading cause of morbidity

*Corresponding author and mortality in neonatal intensive care units, with a reported incidence of $10.1 \%$ among very low birthweight infants ( $<1500 \mathrm{~g}$ ) [1], and a mortality of $26 \%$ [2]. A disease of serious prognosis, advanced cases of NEC may cause multisystem organ failure [3]. Of the 2500 cases occurring annually in the United States [4,5], 20\%-60\% require surgical treatment [6]. At least $80 \%$ of patients are preterm, or have low, or very low birthweight, and the incidence of the disease is inversely proportional to the gestational age $[4,7,8]$. Advances in the supportive care of premature babies, such as use of surfactant, improved technologies for mechanical ventilation, and wider availability of skilled personnel, enable the very premature to survive, and in so doing increase the population of patients susceptible to NEC. Thus, it may bethat medical advances constitute, paradoxically, one reason for the rising incidence of NEC. Infants of extremely low birthweight (under $1000 \mathrm{~g}$ ) and those $28 \mathrm{wk}$ or less of gestational age are at greater risk of NEC than infants closer to term at birth. The severity of the disease and attending complications are greater in infants of extremely low birthweight with more extensive intestinal involvement and higher mortality [9]. 
NEC is uncommon in term infants, in whom it usually appears within 2 to $5 \mathrm{~d}$ after birth, whereas in the preterm it begins at 10 to $15 \mathrm{~d}$ after birth [10]. Presumably, a postnatal insult is followed by the pathogenetic events that lead to the tissue devastation characteristic of NEC. The initiating and pathogenetic factors may differ in patients of different age groups. In any case, the clinical consequences do not differ substantially in the various patient populations, including the infants of extremely low birthweight or extreme prematurity [9]. The symptoms have been staged according to widely used criteria [11,12]. In stage I, the infant manifests abdominal distension (among the most common signs of NEC), vomiting, increased gastric residual, lethargy, apnea, bradycardia, or guaiac-positive stools. These notoriously unspecific manifestations suggest the disease, but they give no indication of the status of the bowel or the prognosis. In stage II, the diagnosis is clearly established, with the appearance of pneumatosis intestinalis or free air in the portal vein. Stage III indicates more advanced disease, as manifested by shock, disseminated intravascular coagulation, acidosis, thrombocytopenia, and sometimes intestinal perforation.

\section{PATHOLOGIC ANATOMY OF NEC: CATALOGUE RAISONE OF THE LESIONS}

The predominant anatomic lesion NEC is coagulative or ischemic necrosis [13-16] (Fig. 1A-C). The usual site is the ileocolic region, as in any intestinal ischemic lesion at any age. Remoteness of the ileocolic artery branches from the main blood supply of the superior mesenteric artery, which also supplies the proximal intestine, may in part explain this susceptibility of localization. In about half the cases the necrosis involves both the small and large intestine, equally divided according to continuous or discontinuous involvement $[15,16]$. The affected bowel is grossly distended, lusterless and gray or greenish-gray, but it may be dark purple or black in areas containing extensive hemorrhage; the soft, fragile wall may perforate when the involvement is severe and transmural. Perforation tends to occur at a junction between normal

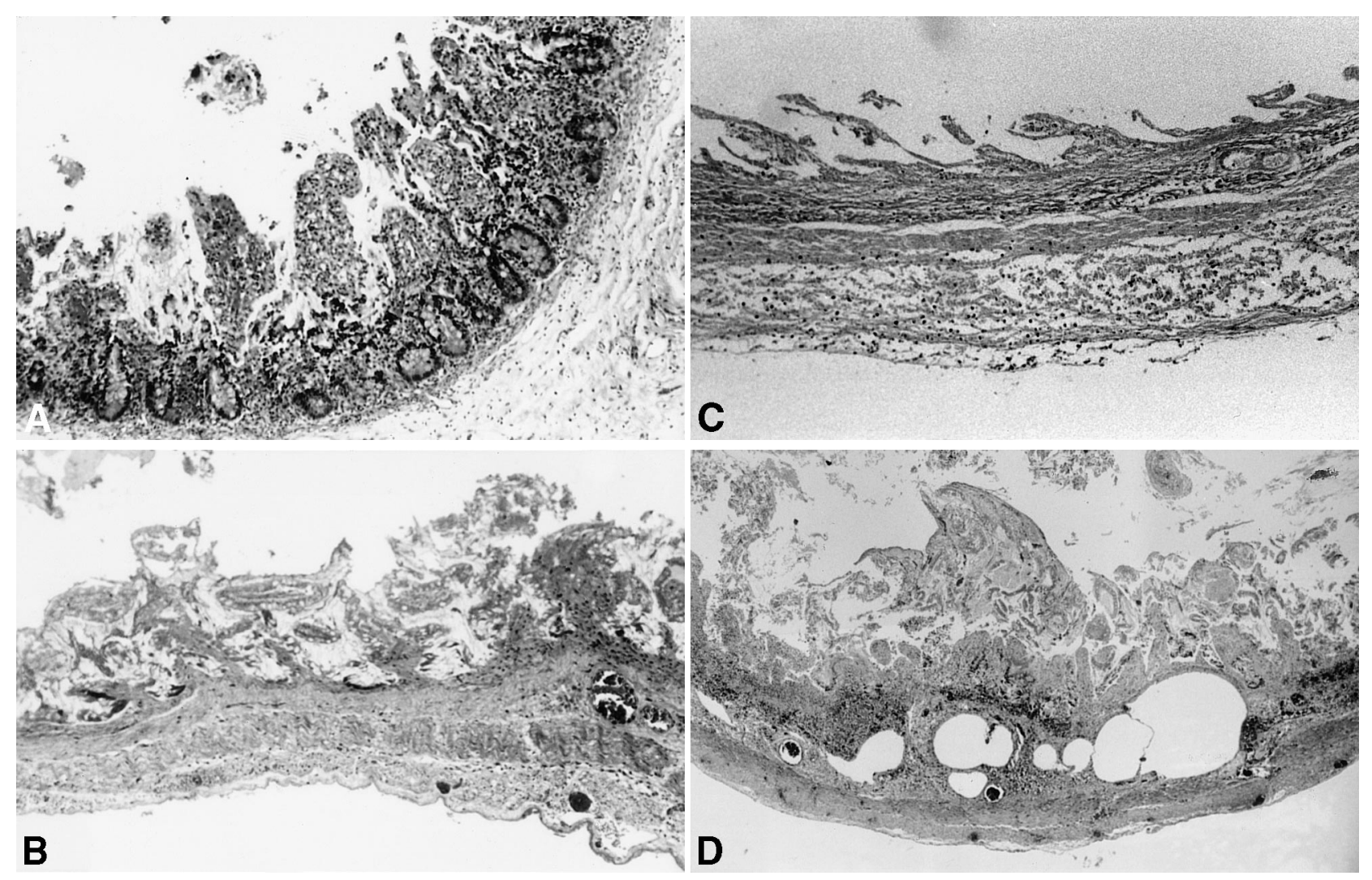

Figure 1. Microscopic appearance of the small intestine from an infant with necrotizing enterocolitis, showing areas of mild mucosal injury (A), extensive mucosal necrosis(B), transmural necrosis(C), and with pneumatosisintestinalis(D). 
and necrotic bowel, but it can occur in the midst of a devitalized region; perforation may occur at more than one site. Gas bubbles, which may be grossly visible in the intestinal wall, are reported to involve the entire colon more commonly in the term infant than in the premature [15].

Ischemia occurs in NEC and accounts for the necrosis, but the mechanism remains unresolved. Nowicki [17] distinguished extrinsic and intrinsic mechanisms of vascular regulation in order to account for the disturbance of vascular supply.

Extrinsic vascular regulation integrates the circulation of the intestine with systemic cardiovascular reflexes. An atavistic "diving reflex" (so named after the physiological changes noted in seals upon diving) [17], has been hypothesized in neonates who experience severe anoxic episodes, during which blood is diverted preferentially to the heart and the brain, in detriment to the circulation of the abdominal organs; the bowel would be exposed to severe ischemia during the event. Although the dive reflex is supported by much experimental evidence in animals [17] and has gained wide acceptance until recent times, it cannot satisfactorily explain all the clinical observations in NEC. The diving reflex presumably takes place as a result of a postulated ischemic insult during parturition [18], whereas the manifestations of NEC usually start during the second week of postnatal life. Vascular reactivity in early postnatal life has been assumed to differ from that of older subjects. However, there is evidence that the intestinal vasculature of 2- to 5-day-old swine manifests autoregulatory "escape" from sustained sympathetic stimulation, in the same manner as the intestine of older animals. Experimentally, sympathoadrenergic stimulation causes transient intestinal vasoconstriction, and normal oxygen uptake is restored after 3 to $5 \mathrm{~min}$ $[19,20]$. Moreover, prospective clinical studies do not always establish an association between neonatal hypoxia or asphyxia and the development of NEC: most patients with NEC have no clinically apparent hypoxemia at birth $[7,17,19]$. These discrepancies by no means exclude an important participation of autonomic neural influences in the development of the intestinal necrosis in NEC. Other extrinsic regulatory mechanisms, such as the participation of therenin-angiotensin axis in bowel ischemia, continue to deserve serious investiga- tion. Angiotensin receptors are densely distributed in the bowel. This may explain why ischemic colitis that develops from mesenteric vasoconstriction during experimental cardiogenic shock cannot be prevented by total adrenergic blockade but is completely abolished by drugs such as captopril, which ablate the renin-angiotensin axis [21].

The intrinsic vasoregulation of the intestine, defined as that "mediated by effector mechanisms produced and released within the intestine and its attendant circulation" [17], has been studied in denervated intestinal segments and other in vivo and in vitro models (for review, see ref. 17). A "metabolic theory" stresses homeostatic control by local tissue need for oxygen, and a "myogenic reflex theory" proposes vasoconstriction in the intestinal circulation in response to changes in venous pressure. Presumably, labile, active myogenic vascular responses in the very young increase their susceptibility to intestinal ischemia [22].

Other "intrinsic" vasoregulatory influences leading to intestinal ischemia include the potent vasoactive agents that are considered central to a theoretical pathogenesis of NEC (videinfra). Admittedly, the clinical situation is necessarily more complex than any hypothetical model centered upon experimental observations. As Kosloske [23] has observed, the chronology of clinical events is not always clear. Obviously, in patients with congenital heart disease and cardiogenic shock or those with a wide pulse pressure and diastolic steal secondary to widely patent ductus arteriosus, hemodynamic disturbances acquire a very significant role in the causation of NEC; but this does not gainsay the utility of clarifying the basic steps by which the disease is initiated and maintained, the factors that modulate it, and the components that may be amenable to therapeutic modification.

Necrosis of the bowel can develop secondary to mesenteric thromboembolism. In neonates thrombosis is usually an untoward effect of the placement of an umbilical artery catheter. However, in most patients with NEC, no thromboembolic episode is suspected clinically, and no occlusion of large arteries can be identified. This observation indicates that NEC and infarction are probably different clinicopathological entities, even though the key morphological feature of both diseases is coagulative necrosis. Infarction results 
from compromised arterial blood supply. Thus, the location and extent of the affected area, which is usually single, should follow the distribution of the arterial blood supply. In contrast, NEC is basically an inflammatory process, therefore the initiating site of the pathophysiology is probably the venule. The location and extent of the affected areas (often multiple) are random, and they are not necessarily related to the arterial supply. Although at early stages the main histological change of NEC is coagulative necrosis, inflammatory cell infiltration is the rule when the disease progresses [16]. Intestinal pneumatosis, the peculiar and characteristic finding seen in many cases of NEC, is not observed in infarcts.

Bacteria are important in causing NEC, since the disease does not occur before the colonization of the intestine by bacteria. In the fetus, whose intestinal contents are sterile, compromise of the blood supply may result in intestinal injury. In the heal ing process atresia or stenosis may devel op but not in typical postnatal NEC. Since bacteria are normal in the lumen of the bowel, they should be expected to proliferate in a segment of devitalized bowel. The degree of bacterial overgrowth in NEC seems to exceed that which takes place in other diseases with ischemic bowel [16]. Pneumatosis intestinalis, the formation of gas bubbles in the wall of the intestine (Fig. 1D), develops largely as a result of the fermentation of intraluminal contents by bacteria and is associated more with NEC than with any other necrotizing condition affecting the intestine. Bacterial production of $\beta$-galactosidase, with its role in reducing $\mathrm{pH}$ by fermentation of lactose, has been suggested as a bacterial activity that contributes to the development of NEC [24]. However, the ability of colonizing bacteria to ferment lactose has not been correlated with the production of NEC [25]; moreover, the endemic cases of NEC are not consistently associated with a single infectious agent or with a particularly virulent organism that produces highly damaging toxins or that displays great entero-invasiveness or entero-aggregative ability. Many microorganisms have been isolated from the stools, and in some cases both from blood and stools, of NEC patients: Escherichia coli, Klebsiella, Enterobacter, Pseudomonas, Salmonella, Clostridium perfringens, Clostridium difficile, Clostridium butyricum [26], coaglu- lase-negative Staphylococci [27], coronavirus, rotavirus, and enteroviruses [28].

Intestinal inflammation affecting about 90\% of the patients with NEC has been interpreted as an appropriate host response to necrosis and proliferating bacteria [16]. Inflammation tends to be less severe following sudden occlusion of the arterial circulation, as with thromboembolism, and much more conspicuous when devitalization of the bowel is gradual. According to Ballance et al. [16], the character of the cellular inflammatory response tends to be different in colitis of infectious origin and in NEC. Microabscesses and crypt abscesses are common in infectious colitis, but they affect only $10 \%$ of patients with NEC. Moreover, extensive necrosis, which may far exceed the degree of inflammation, is a feature of NEC that is generally not found in cases of infectious enterocolitis.

Regenerative changes in NEC are usually marked by replacement of the mucosa by a cuboidal or tall epithelium displaying hyperchromatic nuclei, absent mucin production, and mitotic activity overlying a layer of granulation tissue, or a partly reconstituted lamina propria with distorted, morphologically aberrant glands [14,29]. Regenerative changes may appear even in cases without a protracted history. Ballance et al. [16] found histologic evidence of reparative activity of recent onset in $68 \%$ of the patients, all undergoing surgery for the first time. This finding suggests that NEC is a more insidious process than might be surmised from the acute onset and fulminating course that many patients manifest.

\section{ANIMAL MODEL 1: BOWEL NECROSIS INDUCED BY LIPOPOLYSACCHARIDE, PLATELET-ACTIVATING FACTOR, AND TUMOR NECROSIS FACTOR- $\alpha$}

We developed a model of bowel necrosis in adult rats and mice by injection of endotoxin (lipopolysaccharide, LPS) [30], PAF (platelet-activating factor, paf-acether) [31,32], tumor necrosis factor- $\alpha$ (TNF, cachectin) [33], or a combination of these agents. The rationale for using these agents is as follows. LPS. NEC is clearly associated with intestinal bacterial growth, since NEC usually develops following oral feeding, and oral feeding markedly increases the growth of E. coli in the intestinal tract [34]. 
However, no single infectious agent has been isolated consistently from patients with NEC. We hypothesized that resident intestinal flora such as E. coli and its toxin product, LPS, would be highly probable causative agents of NEC. PAF. Injection of LPS induces endogenous production of PAF $[35,36]$, systemic administration of PAF [37-39] to animals mimicks symptoms and signs of shock, and PAF antagonists prevent LPS-induced shock $[39,40]$. TNF. LPS induces endogenous TNF production $[36,41,42]$ and administration of TNF causes shock $[43,44]$, whereas pretreatment of the animal with anti-TNF [44] ameliorates endotoxin shock and increases survival.

\section{PAF, an endogenous phospholipid with potent proinflammatory actions, causes small intestinal necrosis}

PAF is an endogenous phospholipid mediator produced by inflammatory cells, endothelial cells, platelets $[37,38,45]$, and bacteria of the intestinal flora, such as E. coli [46].

Systemic administration of PAF induces an immediate and sometimes transient hypotensive response. With large doses, the shock becomes profound and irreversible and intestinal necrosis develops rapidly (early injury is usually detectable within $15 \mathrm{~min}$ ). PAF is probably the most potent systemically administered agent for inducing intestinal injury. In our experiments, as little as 2.5 $\mu \mathrm{g} / \mathrm{kg}$ often caused necrosis of the small intestine of varying degree in the rat. Since rat platelets are refractory to PAF $[31,47]$, the pathogenesis of necrosis cannot be due to the thromboembolic effect of PAF. The necrosis is usually focal in the jejunum, ileum, and/or cecum, although more often in the distal ileum. With high doses, the entire small bowel may be affected. Histologically, the necrosis begins at the villous tip (Fig. 2A) [31], often involves the entire villus (Fig. 2B), and may extend to the submucosa or even become transmural (Fig. 2C). Although LPS alone can cause hypotension and intestinal necrosis, the required dosage is often high (>5 mg/kg). However, LPS is a potent "priming" agent for PAF : a small dose of LPS $(600 \mu \mathrm{g} / \mathrm{kg})$ acts synergistically with a low dose of PAF (Table 1) $[31,32,48]$. LPS-induced intestinal injury is blocked by pretreatment with PAF antagonists [30], suggesting that this effect is mediated by endogenous PAF.

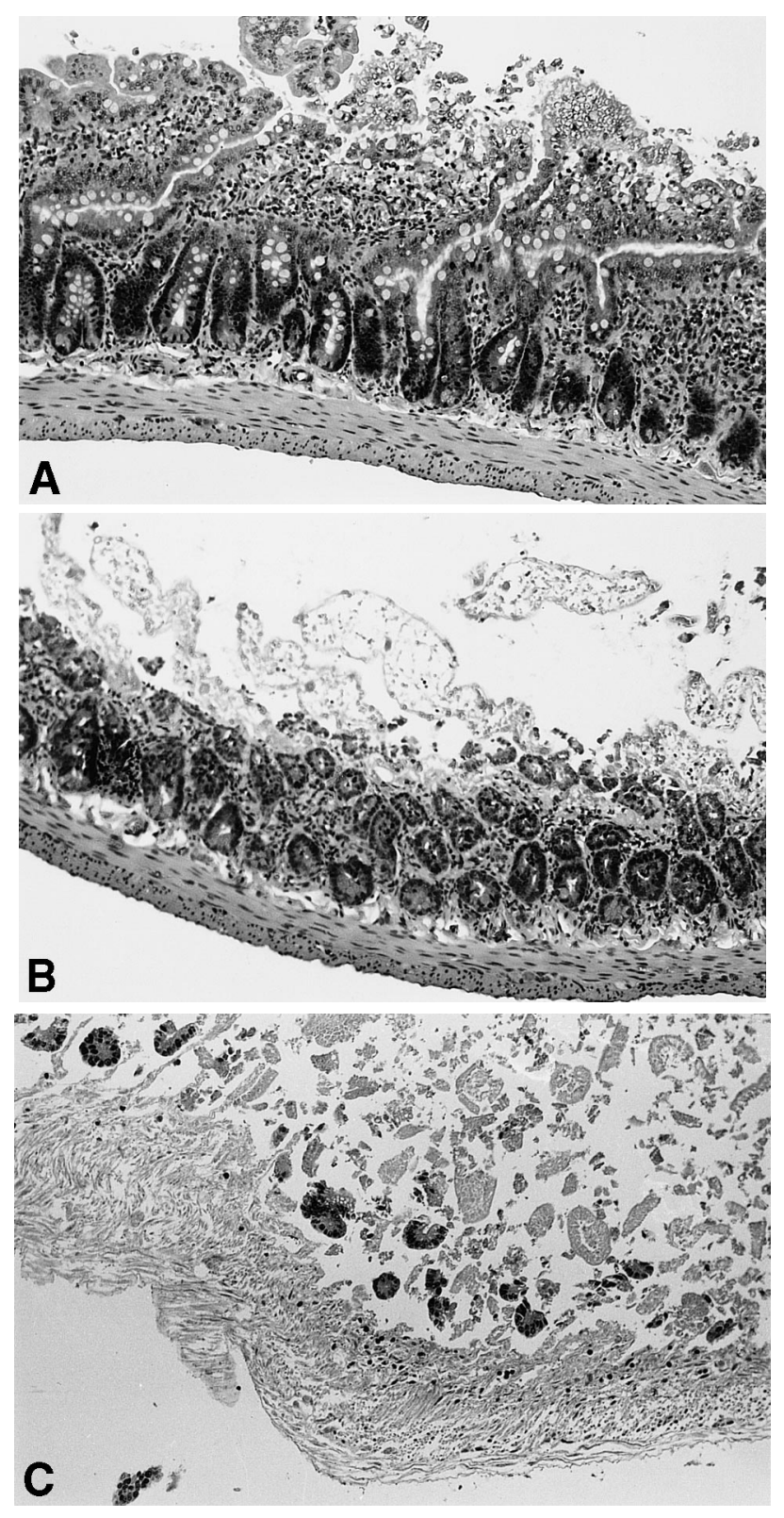

Figure 2. Microscopic appearance of the small intestine from a rat injected with PAF $(2.5 \mu \mathrm{g} / \mathrm{kg})$ showing early stage of intestinal injury with loss of epithelial cells at the villous tips (A), extensive mucosal necrosis with loss of villi (B), and transmural necrosis (C) $(H \& E$ stained).

\section{PAF induces its ow $\mathbf{n}$ production in vivo}

PAF has a short half-life in the blood because of the high activity of acetylhydrolase [49-51], the enzyme that rapidly degrades PAF into the biologically inactive lyso-PAF. Paradoxically, the in vivo action of PAF is prolonged. One mechanism that may account for this prolonged action is that PAF induces its own production in tissues [52]. This is suggested by the observation that PAF antagonists 
Table 1. Synergistic effects of PAF, LPS, and TNF on systemic blood pressure, hematocrit, and intestinal injury in rats $[33,62]^{\text {a }}$

\begin{tabular}{llll}
\hline Agent $(\mathbf{m g} / \mathbf{k g})$ & End blood pressure $(\mathbf{m m ~ H g})$ & Hematocrit & Gross necrosis (\% rats affected) \\
\hline PAF $(0.01)^{\mathrm{a}}$ & $40 \pm 9$ & $59 \pm 2$ & $80 \%{\text { mild, }{ }^{c} \text { 20\% } \text { moderated }^{\mathrm{d}}}$ \\
LPS (2) & $119 \pm 14$ & $44 \pm 2$ & $50 \%$ mild \\
PAF $(0.01)+$ LPS (2) ${ }^{\mathrm{a}}$ & $20 \pm 6$ & $65 \pm 2$ & $100 \%$ moderate \\
LPS $(0.2)^{\mathrm{b}}$ & $95 \pm 6$ & $42 \pm 1$ & None \\
TNF $(0.5)^{\mathrm{b}}$ & $88 \pm 8$ & $44 \pm 1$ & None \\
LPS $(0.2)+$ TNF $(0.5)^{\mathrm{b}}$ & $20 \pm 5$ & $46 \pm 3$ & $80 \%$ moderate, 20\% mild
\end{tabular}

aAll values were obtained $30 \mathrm{~min}$ after the injection of PAF.

bAll values were obtained $2 \mathrm{~h}$ after the injection of TNF.

cMild necrosis: involving top third of villi.

dModerate necrosis: involving more than top one-third of villi, but confined to the mucosa.

decrease PAF-induced PAF production in the intestine (Table2) [30,52].

\section{TNF induces intestinal injury and endogenous PAF production}

TNF is produced mainly by mononuclear phagocytes [41,53] but also by lymphocytes [53] and other cells [54] upon appropriate stimulation. TNF has many proinflammatory actions [55-57], such as inducing leukocyte and endothelial adhesive molecules, activating polymorphonuclear leukocytes (PMNs) and endothelial cells, and causing production of other cytokines [55-57], including TNF itself [55-57], eicosanoids [55,56], and PAF $[58,59]$. Intravenous injection of TNF (1 mg/kg) also induces hypotension and mild intestinal injury in rats [33]. The effect of TNF and LPS are synergistic: TNF (0.5 mg/kg), when combined with LPS

Table 2. List of drugs that prevent or ameliorate PAF-induced intestinal necrosis in rats

\begin{tabular}{|c|c|c|c|}
\hline Agent & Dose (mg/kg) & Mechanism & Reference \\
\hline FPL 55712 & 5 & LTC4/D4 antagonist & 32 \\
\hline ICl 198615 & $10-20$ & LTC4/D4 antagonist & 72 \\
\hline Phenoxybenzamine & 20 & Alpha blocker & 72 \\
\hline $\begin{array}{l}\text { Superoxide } \\
\text { dismutase + catalase }\end{array}$ & $@ 10^{a}$ & Oxygen radical scavenger & 75 \\
\hline Allopurinol & 5 & Xanthine oxidase inhibitor & 75 \\
\hline WEB 2086 & 1 & $\begin{array}{l}\text { PAF antagonist, also } \\
\text { blocks endogenous PAF } \\
\text { production }\end{array}$ & 52 \\
\hline PGE 1 & $0.27^{a}$ & $\begin{array}{l}\text { Vasodilation, cytoprotec- } \\
\text { tion, inhibits norepi- } \\
\text { nephrine }\end{array}$ & 72 \\
\hline Combined antibiotics ${ }^{b}$ & & Diminish gut flora & 68 \\
\hline Vinblastine & 0.75 & PMN depletion & 61 \\
\hline Anti-PMN serumc & & PMN depletion & 78 \\
\hline Anti-CD18 & 0.5 & Blocks PMN adhesion & 78 \\
\hline Anti-CD11b & 1.5 & Blocks PMN adhesion & 78 \\
\hline+ Anti-CD11a & 0.67 & & \\
\hline
\end{tabular}


(200 $\mu \mathrm{g} / \mathrm{kg}$ ), causes profound shock and severe intestinal necrosis [33] in rats and mice [60,61]. PAF is probably the endogenous mediator for TNF/ LPS, since PAF was detected after administration of TNF/LPS [61], and pretreatment with a PAF receptor antagonist protects mice from shock induced by TNF/LPS, intestinal injury, and death (Table 1) [61].

\section{PAF induces TNF expression and activates transcription factor NF- $\kappa$ B in the intestine}

The splanchnic bed has been reported to be a major source of TNF production in vivo. We have shown that LPS (2 mg/kg) and PAF ( $1 \mu \mathrm{g} / \mathrm{kg}$ ), at doses below those causing shock and intestinal injury, stimulateTNF geneexpression and protein production in the rat's liver and small intestine, predominantly in the ileum [62] (Fig. 3). WEB-2086, a PAF antagonist, only partial ly blocked LPS-induced TNF mRNA formation (Fig. 3), suggesting that LPS induces TNF formation via both PAF-dependent and PAF-independent pathways. Since TNF is constitutively expressed at low levels in the intestine, TNF production requires de novo synthesis. Production of many proinflammatory cytokines, including TNF, is regulated by transcription factors, such as nuclear factor $\kappa B(N F-\kappa B)$ [63]. TNF activates $N F-\kappa B$ in vitro $[63,64]$, a pathway that may be involved in TNF's self-activation. Low doses of TNF (1 mg/kg) and PAF (1 $\mu \mathrm{g} / \mathrm{kg})$, which are below those

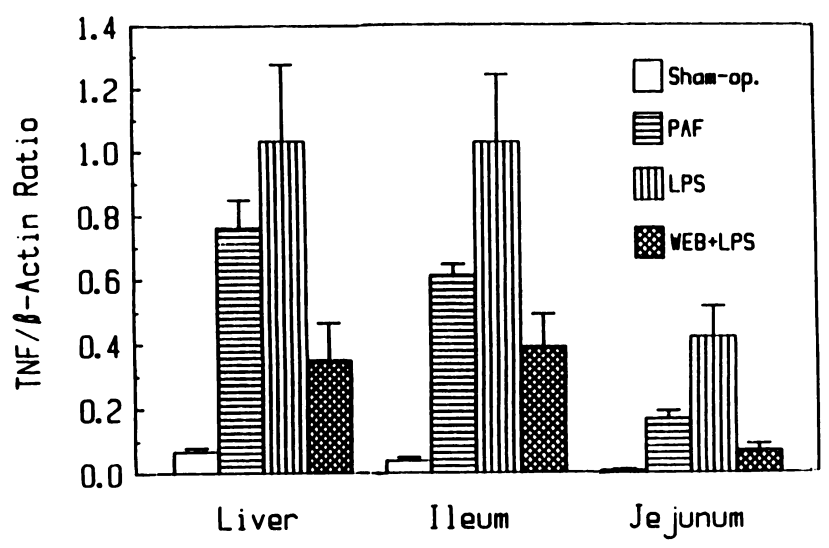

Figure 3. PAF induces TNF mRNA production in the rat liver and ileum. mRNA from the liver and the small intestine was extracted 30 min after injection of a low dose $(1 \mu \mathrm{g} / \mathrm{kg})$ of PAF. Results calculated from Northern blot analysis [62]. $\beta$-Actin, a housekeeping gene, is used as the common denominator for calculation, and quantity of TNF mRNA is expressed as ratio of TNF mRNA/ $\beta$ actin mRNA. causing shock and intestinal injury, increase the mRNA of NF-кB precursor, p50/p105, in the small intestine [65]. The action of PAF is as potent as, but more rapid than, than of TNF [65].

\section{Importance of endogenous LPS}

Although injection of PAF results in circulatory shock and intestinal necrosis, it is unclear whether the in vivo effect of PAF is exerted directly or via the action of other factors. We showed that endogenous bacterial toxins (from the intestinal lumen) play an important role in PAF-induced shock and bowel injury: (1) systemic entry of bacteria or their toxins is a complication of experimental sepsis [66]; (2) PAF acts synergistically with exogenous LPS to cause shock and intestinal injury [32]; (3) endotoxin-resistant mice are protected from PAFinduced intestinal injury [67]; (4) germ-free rats are protected from PAF-induced prolonged shock and bowel injury, and the protection is lost when these animals are primed with exogenous LPS [68]; and (5) conventional rats treated with combined antibiotics (a mixture of neomycin, $250 \mathrm{mg} / \mathrm{kg} / \mathrm{d}$, polymyxin B, $9 \mathrm{mg} / \mathrm{kg} / \mathrm{d}$ and metronidazole, $50 \mathrm{mg} / \mathrm{kg} / \mathrm{d}$ for 1 wk), which markedly decreases the bacterial content in the bowel lumen, are protected to a large extent from the injurious effects of PAF [68] (Table 2). Polymyxin $B$ alone had no protective effect. These observations suggest that PAF causes intestinal injury and deleterious systemic changes via a synergistic action with endogenous bacterial polymer toxins, presumably from intestinal bacteria. LPS may not be the only bacterial product that synergizes with PAF to produce tissue damage, since polymyxin B alone was without protective effect [68].

\section{Other mechanisms in intestinal injury: leukotrienes, catecholamines, the complement system, reactive oxygen species (ROS), phospholipase $A_{2}$, and PMN-endothelial adhesion}

PAF has a prolonged in vivo action despite its short half-life in the circulation. Furthermore, PAF is a vasodilator in vitro [69], whereas at high dose its effect on the splanchnic bed is sustained vasoconstriction $[69,70]$. To reconcile these apparently paradoxical effects, we hypothesized that secondary mediators with splanchnic vasoconstricting action, such as leukotriene (LT) $\mathrm{C}_{4}$ [71] and norepi- 
nephrine [72], are released after PAF injection. Moreover, in vivo administration of antagonists to peptide leukotrienes $[32,70]$, or alpha blockers [70], did not reverse shock but prevented PAFinduced intestinal injury (Table 2).

Injection of PAF activates the complement system in vivo [61], and C5 deficient mice are protected from TNF/LPS- or PAF-induced injury $[60,61]$, suggesting a role of the complement system in the development of bowel injury.

The cytotoxicity effect of PAF is most likely due to formation of reactive oxygen species (ROS), since infusion of superoxide dismutase and catalase [73], or pretreatment with allopurinol [73], a xanthine oxidase inhibitor, considerably ameliorated PAF-induced bowel necrosis (Table 2).

The source of these secondary mediators is unknown. Peptide leukotrienes, oxygen radicals, and endogenous PAF and cytokines are likely to originate, at least in part, from the resident or infiltrating inflammatory cells. Although macrophages [58], mast cells [74,75], and endothelial cells $[58,76,77]$ are capable of elaborating these mediators, virtually nothing is known about the secretory profiles of these cells in the intestine. Adhering PMNs may play an important role in mediating tissue injury, probably via release of ROS and proteolytic enzymes, since depletion of PM Ns by vinblastine [61] or anti-neutrophil antiserum [78] prevents PAF- or PAF/LPS-induced intestinal injury. The importance of PMN-endothelial adhesion in mediating intestinal injury is also demonstrated by the observations that anti-CD18 ( $\beta_{2}$-integrin on PMNs) prevents the PAF-induced increased endothelial [79] and mucosal [80] permeability, and anti-CD11b or anti-CD18 largely blocks PAF-induced bowel injury [78]. Other adhesion molecules such as selectins may also play a role in mediating intestinal injury, since genetically altered mice deficient in P-selectin were totally protected from PAF-induced necrosis [81]. Furthermore, ICAM-1-deficient mice pretreated with fucoidin (blocking P- and L-selectins) also developed much milder bowel injury, compared with wild-type mice [81].

Another nonimmune cell that may be involved in the pathogenesis of intestinal injury is the Paneth cell, which constitutively expresses low levels of TNF [82]. However, TNF gene expression in Paneth cells, lamina propria eosinophils, and infiltrating (but not resident) macrophages increases in infants during the acute stage of NEC [83]. Paneth cells are also rich in group II phospholipase $A_{2}\left(P L A_{2}-1\right.$ ) [84], a protein implicated in many inflammatory responses and in sepsis [84]. PAF also enhances PLA P $_{2}-\mathrm{II}$ gene expression and enzyme activity in the small intestine [85].

\section{ANIMAL MODEL 2: HYPOXIA AND LPS/HYPOXIA IN EXPERIMENTAL NEC}

Several conditions involving decreased oxygen delivery to the mesenteric circulation are associated with an increased risk of NEC in human infants. These conditions include those associated with decreased blood oxygen content, such as asphyxia [86] and cyanotic congenital heart disease [87], and those associated with decreased mesenteric blood flow, such as intrauterine growth retardation [88] and maternal cocaine use [89]. Animal models of NEC have shown that hypoxia is associated with development of ischemic bowel necrosis [90] but did not define the mechanism of bowel injury.

We first explored the role of hypoxia in the pathogenesis of ischemic bowel necrosis using young (25- to 30-day-old) adult male SpragueDawley rats [91]. The animals were exposed to either acute severe hypoxia, effected by placing them in $100 \%$ nitrogen for $2 \mathrm{~min}$, or to subacute moderate hypoxia, effected by placing them in a $10 \%$ oxygen atmosphere for 15 or $30 \mathrm{~min}$. We found that $30 \mathrm{~min}$ of moderate hypoxia resulted in mild to moderate ischemic bowel necrosis, with no evidence of necrosis in any other organ. The bowel injury was prevented by two structurally unrelated PAF antagonists, WE B 2086 and SRI 63-441. Plasma levels of PAF were markedly elevated in theanimals treated with 30 min of moderate hypoxia when compared with controls and were also elevated in animals treated with only 2 min of acute severe hypoxia [91]. On the basis of these results, we concluded that hypoxia results in a rapid increase in endogenous PAF levels and that PAF is a mediator of hypoxic intestinal injury.

The etiology of NEC is multifactorial. In addition to decreased mesenteric oxygen delivery, bacterial colonization of the gastrointestinal (GI) tract is generally held to be an important requisite for the development of NEC [92]. Theimportance of bacte- 
ria in the pathogenesis of NEC can beinferred from the observations that full-blown ischemic bowel necrosis cannot be reproduced in a sterile animal model [93], and, although bowel infarction can certainly occur in the fetus, typical NEC has never been reported as present at birth or in a stillborn infant [14]. Because hypoxia alone produced relatively mild bowel injury in our model, we hypothesized that hypoxia and bacterial endotoxin (LPS) might act synergistically to produce more severe bowel injury.

We treated young adult male Sprague-Dawley rats with either hypoxia alone (5\% oxygen for 90 $\mathrm{min}$ ), LPS alone ( $2 \mathrm{mg} / \mathrm{kg}$ Salmonella typhosa endotoxin i.v.), or LPS + hypoxia (LPS given at $0 \mathrm{~min}$ followed $90 \mathrm{~min}$ later by hypoxia for $90 \mathrm{~min}$ ) [94]. Both LPS alone and hypoxia alone caused little or no intestinal injury, whereas combined treatment with LPS and hypoxia resulted in significantly worse gross and microscopic intestinal injury. This injury was significantly ameliorated by treatment with either WEB 2086 or SRI 63-441. Animals treated with LPS + hypoxia tended to have higher plasma PAF levels than animals in the other groups, but the difference did not reach statistical significance in this study. Both LPS and LPS + hypoxia caused a significant increase in plasma TNF levels. We concluded that LPS and hypoxia act synergistically to produce bowel necrosis and that PAF is an important mediator in this process.

In the vascular endothelium, nitric oxide(NO) synthesized from L-arginine by the constitutive form of nitric oxide synthase limits neutrophil adhesion, promotes microvascular integrity, and maintains basal vasodilator tone [95]. We explored the role of endogenous NO in the pathogenesis of hypoxia-induced intestinal injury [96,97]. Inhibition of endogenous NO production with L-arginine analogs significantly worsened the bowel injury produced by $90 \mathrm{~min}$ of $10 \%$ oxygen exposure, suggesting that endogenous NO production constitutes an important defense mechanism against hypoxia-induced intestinal injury. PAF levels were significantly elevated in the intestines of animals treated with hypoxia and an NO synthase inhibitor, and the intestinal injury seen in these animals was prevented with the PAF antagonist WEB 2086. These findings agree with those of a related study, in which inhibition of endogenous NO production markedly worsened the bowel injury and intestinal neutrophil accumulation caused by PAF [97].

\section{ANIMAL MODEL 3: NEONATAL NEC: ROLE OF HYPOXIA, ENTERAL FEEDING, AND ENDOGENOUS PAF}

A major challenge in understanding the pathogenesis of NEC in human infants is the lack of the perfect experimental animal model. Although several animal models have been used, most lack some or all of the cardinal features of the human condition. The adult rat model serves well to characterize the role of PAF and other mediators in acute ischemic bowel necrosis. However, it lacks the critical predisposing feature of prematurity, leaving information regarding the role of PAF in NEC as speculative.

To characterize the role of PAF in NEC, we considered experiments on neonatal animals [98100]. The model of Barlow et al. [100], first described in 1972, most closely reproduced the symptoms and signs of human NEC. In this model, newborn rat pups were removed from their mother, exposed to maternal milk, stressed briefly with asphyxia, colonized with gram-negative enteric bacteria, and fed with artificial formula. By the third day of life, most animals developed abdominal distention and discoloration, bloody stools, respiratory distress, cyanosis, hemorrhagic intestinal necrosis, and microscopic evidence of severe necrosis identical to the pathology observed in neonatal NEC. In this model, maternal milk, milk leukocytes, immunoglobulin, and oral antibiotics were identified as important for the prevention of NEC [101,102].

We set out to reproduce the findings of Barlow et al. and to better characterize the pathologic findings [103]. Neonatal rats delivered via abdominal incision were maintained in a neonatal incubator and received the following stresses: (1) artificial formula feedings $(0.1 \mathrm{ml}$ every $3 \mathrm{~h}$ via orogastric tube, $200 \mathrm{cal} / \mathrm{oz}$, advanced as tolerated; (2) asphyxia (100 $\mathrm{N}_{2}$ for 50 s twice daily; and (3) E. coli inoculation $\left(1 \times 10^{9}\right.$ organisms/d via orogastric tube). Our data (Table 3 ) confirm that both asphyxia and formula feeding together are necessary to produce NEC in this model. Enteral bacterial inoculation was not a critical factor in our model since more than half of the animals treated with 
Table 3. Effect of experimental protocol on neonatal NEC and mortality

\begin{tabular}{llllll}
\hline $\begin{array}{l}\text { Number of } \\
\text { animals }\end{array}$ & Bacteria & Hypoxia & Formula & $\begin{array}{l}\text { NEC } \\
\text { (\%) }\end{array}$ & $\begin{array}{l}\text { Death } \\
\text { (\%) }\end{array}$ \\
\hline 22 & + & + & + & 77 & 86 \\
8 & + & - & + & 0 & 12 \\
13 & + & + & - & 0 & 0 \\
14 & - & + & + & 57 & 57 \\
$8^{a}$ & + & + & + & 75 & 100 \\
$8^{a}$ & - & - & + & 38 & 75
\end{tabular}

apreterm rat pups.

asphyxia and formula alone developed disease ( $P=N S$, not significant) compared to asphyxia, formula, and bacteria. Pathologic findings were similar to symptoms of human NEC. Grossly, the intestine was violaceous purple, hemorrhagic, with friable, occasionally segmental lesions, but often involving most of the intestinal length. Histopathologically, moderate to severe injury in most animals was characterized by villous necrosis extending to the submucosa (Fig. 4A,B) and often transmural necrosis (Fig. 4C,D). These data confirmed the similarity of the newborn rat model of NEC to the human disease.

To evaluate the role of PAF in this neonatal rat model of NEC [104], animals stressed with asphyxia, formula feeding, and bacterial inoculation were compared with those pretreated with the PAF receptor antagonists WEB 2170 and WEB 2086 (generous gift from Dr. H. Heuer, Boehringer Ingelheim, Mainz, Germany) and then subjected to the experimental protocol. WEB 2170 in appropriate enteral dosing (10 $\mathrm{mg} / \mathrm{kg} \mathrm{q}$ am/30 $\mathrm{mg} / \mathrm{kg} \mathrm{q} \mathrm{pm}$ ) significantly reduced the incidence of NEC and death compared with controls (Table 4). A 4-fold higher WEB 2170 dosing regimen did not alter the incidence of NEC, presumably because of an ago-
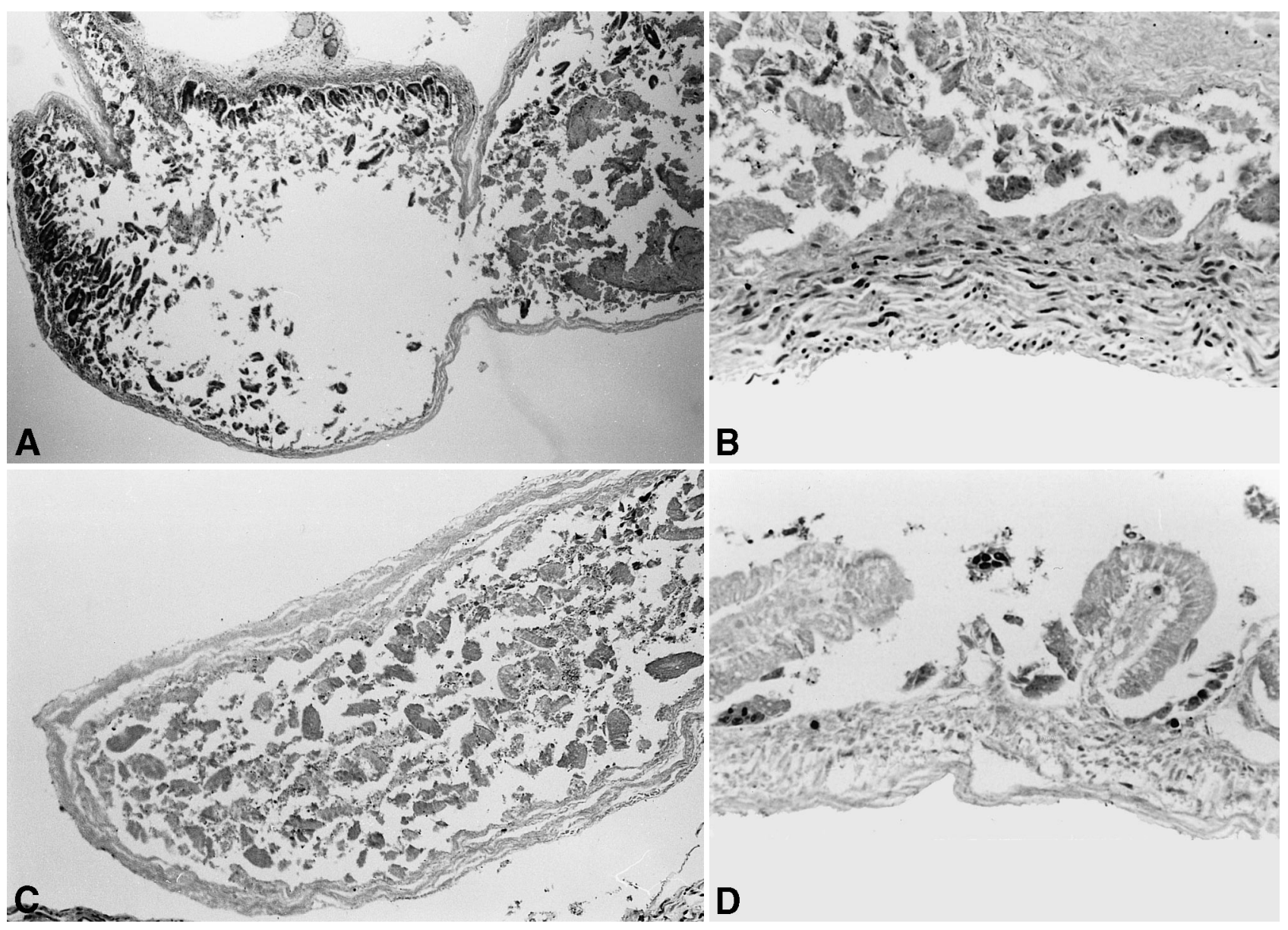

Figure 4. Necrotizing enterocolitis in neonatal rats subjected to asphyxia, formula feeding, and bacteria ingestion. A,B: A small intestinal loop showing necrosis with loss of villi. C,D: Areas of transmural necrosis ( $\mathrm{H} \& \mathrm{E}$ stained). A and $C$, low magnification; $B$ and $D$, high magnification. 
Table 4. Effect of PAF receptor antagonists on death and NECa

\begin{tabular}{|c|c|c|c|}
\hline & $\begin{array}{l}\text { WEB } 2170 \\
(10 / 30 \mathrm{mg} / \mathrm{kg})\end{array}$ & $\begin{array}{l}\text { WE B } \\
2170 \times 4 \\
(30 / 120 \\
\mathrm{mg} / \mathrm{kg})\end{array}$ & $\begin{array}{l}\text { WE B } 2086 \\
(10 / 30 \\
\mathrm{mg} / \mathrm{kg})\end{array}$ \\
\hline \multicolumn{4}{|l|}{ NEC } \\
\hline Control & 14/18 (78\%) & $10 / 12$ (83\%) & 9/12 (75\%) \\
\hline $\begin{array}{l}\text { WEB } \\
\text { treatment }\end{array}$ & $3 / 17$ (18\%)* & 9/11 (82\%) & $7 / 13$ (54\%) \\
\hline \multicolumn{4}{|l|}{ Death } \\
\hline Control & 17/18 (94\%) & $11 / 12(92 \%)$ & 9/12 (75\%) \\
\hline $\begin{array}{l}\text { WEB } \\
\text { treatment }\end{array}$ & $6 / 17(35 \%)^{*}$ & 10/11 (91\%) & 9/13 (69\%) \\
\hline \multicolumn{4}{|c|}{$\begin{array}{l}\text { *P }<0.001 \text { using Fisher's exact test. } \\
\text { aWEB dosing regimen represents a.m./p.m. dosing schedule. WEB } 2086 \\
\text { and WEB 2170: PAF antagonists (gifts from Boehringer Ingelheim, } \\
\text { Mainz, Germany). }\end{array}$} \\
\hline
\end{tabular}

nist effect on the PAF receptor at very high doses [105]. In contrast, WEB 2086 did not reduce the incidence of NEC in stressed animals. Since WEB 2086 has a much shorter half-life than WEB 2170, it is presumed that inadequate PAF receptor blockade was achieved in this dosing regimen. Intestinal PAF concentrations were el evated $(270 \pm 80 \mathrm{pg} / \mathrm{g})$ in animals stressed with asphyxia, formula feeding, and bacterial inoculation compared with agematched, healthy, maternally fed controls (70 \pm 50 $\mathrm{pg} / \mathrm{g}, \mathrm{P}<0.05)$. The data support the hypothesis that PAF acts as a critical mediator in this neonatal rat model of NEC.

Experimental studies on phospholipase support the role of PAF in the neonatal rat model. Phospholipase $A_{2}\left(P L A_{2}\right)$ consists of a diverse family of enzymes with potent biological activity [106]. Group II PLA 2 , a secretory form of PLA ${ }_{2}$, appears to be important in the inflammatory cascade and may regulate PAF production [107]. The regulation of group II $\mathrm{PLA}_{2}$ mRNA in intestine from animals stressed with asphyxia, formula feeding, and bacterial inoculation was compared with control, maternally fed animals. Northern blot analysis using a cDNA probe for group II PLA $\mathrm{P}_{2}$ showed an almost 3.9-fold increase in mRNA in the stressed animals compared with controls $[n=6$ in each group, Caplan et al., unpublished observations), further supporting the role of PAF activation in the development of NEC.

\section{CORRELATION OF HUMAN NEC WITH EXPERIMENTAL NEC}

Experimental evidence strongly supports the role of PAF, LPS, and TNF in acute ischemic bowel necrosis and in the neonatal rat model of NEC. Some data from human studies suggest a similar pathophysiology in neonatal NEC. Local and systemic PAF concentrations are quite elevated in neonates with NEC, and feeding alone promotes PAF production. We found higher circulating plasma PAF concentrations in NEC patients compared with age-matched, illness-matched controls [108]. These NEC patients also had higher circulating TNF- $\alpha$ levels and lower plasma acetylhydrolase activity (PAF-degrading enzyme) than control babies. Enteral feeding itself caused elevations of circulating PAF levels in a significant percentage of preterm infants [109], although the circulating acetylhydrolase activity was not affected by the feeding regimen. Circulating levels of PAF may not adequately reflect the activity in the local environment (intestinal lumen/mucosa), but stool PAF concentrations also increased with feedings, and by $14 \mathrm{~d}$ after feedings were begun, the PAF levels were approximately 3-fold higher than prefeeding values (1028 \pm 244 pg/g vs. $357 \pm 76$ pg/g, $P<0.05$ ) [110]. Stool samples from seven patients with NEC (stage II or III) had the highest levels, with a mean PAF concentration 8-fold higher than controls (2484 $\pm 154 \mathrm{pg} / \mathrm{g})$.

The apparent increased PAF production in experimental and human NEC fails to explain why NEC exclusively afflicts newborn infants. Several factors may predispose newborns and especially premature infants to NEC, e.g., immature gastrointestinal host defense or dysfunctional mesenteric blood flow autoregulation, but another potential abnormal function is the PAF-degrading enzyme acetylhydrolase (PAF-AH) [111,51]. Although plasma PAF-AH activity is lower in NEC patients than in controls [108], PAF-AH activity is low in newborns as a group, reaching normal adult values at 6 wk of life [112]. Breast milk-fed (containing significant PAF-AH activity) neonates have a much lower risk of NEC than formula-fed (without measurable PAF-AH activity) babies [113]. In animal experiments, upregulation of PAF-AH can prevent ischemic bowel necrosis following exogenous PAF infusion [114]. The data strongly support the role 
of PAF in neonatal NEC and suggest that abnormal PAF-AH activity in the newborn may in part explain the predilection of NEC for this age group.

\section{PROPOSED MECHANISM FOR THE PATHOGENESIS OF NEC (FIG. 5)}

We hypothesize that the initial insult in the chain of events leading to NEC could be perinatal hypoxia or a postnatal mild infection, which results in mild

Perinatal hypoxia

Mild infection, etc.

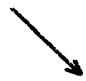

Mild mucosal damage

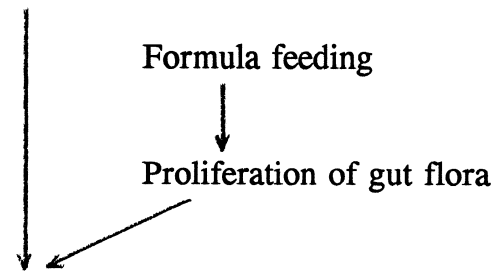

Bacterial adhesion to epithelia

Release of LPS \& other bacterial products

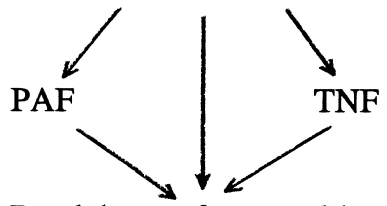

Breakdown of mucosal barrier

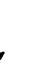

Entry of bacteria and their products
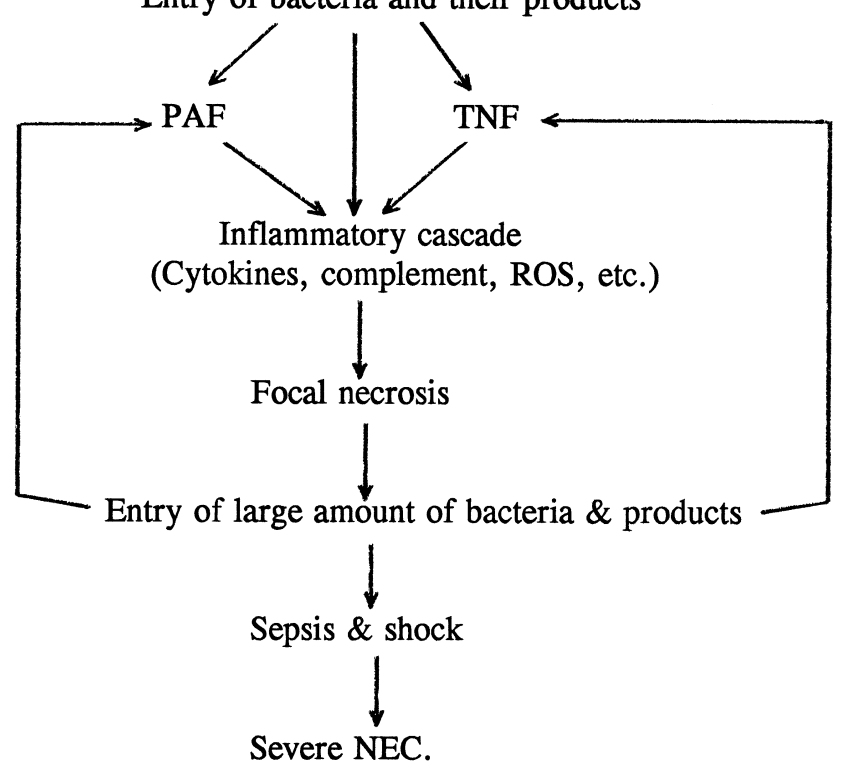

Figure 5. Flow diagram for the proposed pathogenesis of necrotizing enterocolitis. mucosal damage. Following formula feeding and the proliferation of the intestinal flora, bacteria may attach to the damaged intestinal epithelia because of immaturity of the "mucosal barrier," eliciting endogenous production of PAF and TNF. Although gut bacteria may themselves form PAF, the normal mucosal barrier probably prevents any deleterious action on the epithelium. However, in immature or mildly damaged mucosa, the close proximity of bacteria and intestinal epithelial cells may facilitate transcellular permeation of PAF into the mucosa. If the acetylhydrolase is deficient, PAF, which increases the intestinal epithelial permeability in vivo [80]), may accumulate locally and further break down the mucosal barrier, resulting in local entry of bacteria or bacterial products. PAF may then synergize with LPS and/or TNF, reaching the necessary threshold to trigger a cascade of inflammatory events: PMN adhesion and activation, complement activation, and release of other inflammatory mediators as well as cytotoxic reactive oxygen species. The result could bethe development of focal intestinal necrosis, which further promotes bacterial entry, thereby launching a selfperpetuating vicious cycle, leading to shock, sepsis and, sometimes, death.

\section{ACKNOWLEDGMENTS}

This work was supported by NIH grants DK 34574, HD 31840, and HD00999.

\section{REFERENCES}

1. Uauy R, Fanaroff $A A$, Korones $S$, et al. Necrotizing enterocolitis in very low birthweight infants: Biodemographic and clinical correlates. J Pediatr 1991;119:630638.

2. Hack M, Horbar J, Malloy $M$, et al. Very low birthweight outcomes of the National Institute of Child Health and Human Development neonatal network. Pediatrics 1991; 87:587-597.

3. Morecroft JA, Hamilton PA, Holmes SJ K. Necrotizing enterocolitis-multisystem organ failure of the newborn? Acta Paediatr (Suppl) 1994;396:21-23.

4. Kliegman RM, Fanaroff AA. Medical progress: Necrotizing enterocolitis. N Engl J Med 1984;310:1093-1103.

5. Brown EG, Sweet AY. Neonatal necrotizing enterocolitis. Pediatr Clin North Am 1982;29:1149-1170.

6. Gupta SK, Burke G, Herson VC. Necrotizing enterocolitis: Laboratory indicators of surgical disease. J Pediatr Surg 1994;29:1472-1475.

7. Stoll J, Kanto WP J r, Glass R, et al. Epidemiology of necrotizing enterocolitis: A case control study. J Pediatr 1980;96:447-451.

8. De Curtis M, Paone C, Vetrano G, et al. A case control study of necrotizing enterocolitis occurring over 8 years 
in a neonatal intensive care unit. Eur J Pediatr 1987;146: 398-400.

9. Rowe MI, Reblock KK, KurkchubascheAG, et al. Necrotizing enterocolitis in the extremely low birth weight infant. J Pediatr Surg 1994;29:987-991.

10. Hollwarth ME. Necrotizing enterocolitis: An editorial. Acta Paediatr (Suppl) 1994;396:1.

11. Bell MJ , Ternberg J L, Feigin RD, et al. Neonatal necrotizing enterocolitis. Ann Surg 1978;187:1-7.

12. Walsh MC, Kliegman RM. Necrotizing enterocolitis: Treatment based on staging criteria. Pediatr Clin North Am 1986;33:179-201.

13. Benirschke K. Pathology of neonatal enterocolitis. In: Moore TD, ed. Necrotizing Enterocolitis in the Newborn Infant: Report of the 68th Ross Conference on Pediatric Research. Columbus, Ohio: Ross Laboratories, 1974;2930.

14. DeSa DJ. The spectrum of ischemic bowel disease in the newborn. Perspect Pediatr Pathol 1976;3:273-309.

15. Polin RA, Pollack PF, Barlow B, et al. Necrotizing enterocolitis in full-term infants: A case-control study. J Pediatr 1976;89:460-462.

16. Ballance WA, Dahms BB, Shenker N, et al. Pathology of neonatal necrotizing enterocolitis: $A$ ten-year experience. J Pediatr 1990;117:S6-S13.

17. Nowicki P. Intestinal ischemia and necrotizing enterocolitis. J Pediatr 1990;117:S14-S19.

18. Lloyd JR. The etiology of gastrointestinal perforations in the newborn. J Pediatr Surg 1969;4:77-84.

19. Kliegman RM, Hack M, J ones P, Fanaroff AA. Epidemiologic study of necrotizing enterocolitis among low-birthweight infants. J Pediatr 1982;100:440-444.

20. Ross G. Escape of mesenteric vessels from adrenergic and nonadrenergic vasoconstriction. Am J Physiol 1971;221: 1217-1222.

21. Bailey RW, Hamilton SR, Morris JB, et al. Pathogenesis of nonocclusive ischemic colitis. Ann Surg 1986;203:590599.

22. Crissinger KD, Kvietys PR, Granger DN. Developmental intestinal vascular responses to venous pressure elevation. Am J Physiol 1981;130:537-542.

23. Kosloske AM. A unifying hypothesis for pathogenesis of necrotizing enterocolitis. J Pediatr 1990;117:S68-S74.

24. Carbonaro CA, Clark DA, Elseviers D. A bacterial pathogenicity determinant associated with necrotizing enterocolitis. Microb Pathog 1988;5:427-436.

25. Gupta S, Morris J G, Panigrahi P, et al. Endemic enterocolitis: Lack of association with a specific infectious agent. Pediatr Infect DisJ 1994;13:728-734.

26. Kliegman RM, Fanaroff AA, Izant R. Clostridia as pathogens in necrotizing enterocolitis. J Pediatr 1979;95:287289.

27. Mollitt DL, Tepas JJ, Talbert J L. The role of coagulase negativestaphylococcus in neonatal necrotizing enterocolitis. J Pediatr Surg 1988;23:60-63.

28. Rotbart HA, Nelson WL, Glode MP, et al. Neonatal rotavirus-associated necrotizing enterocolitis: Case control study and prospective surveillance during an outbreak. J Pediatr 1988;112:87-93.

29. Joshi VV, Winston YE, Kay S. Neonatal necrotizing enterocolitis: Histologic evidence of healing. Am J Dis Child 1973;126:113-116.

30. Hsueh W, Gonzalez-Crussi F, Arroyave JL. Plateletactivating factor: An endogenous mediator for bowel necrosis in endotoxemia. FASE B J 1987;1:403-405.

31. Gonzalez-Crussi F, Hsueh W. Experimental model of ischemic bowel necrosis. The role of platelet-activating factor and endotoxin. Am J Pathol 1983;112:127-135.
32. Hsueh W, Gonzalez-Crussi F, Arroyave JL. Plateletactivating factor-induced ischemic bowel necrosis. An investigation of secondary mediators in its pathogenesis. Am J Pathol 1986;122:231-239.

33. Sun XM, Hsueh W. Bowel necrosis induced by tumor necrosis factor in rats is mediated by platelet-activating factor. J Clin Invest 1988;81:1328-1331.

34. Brown EG, Ainbender E, Henley WL, Hodes HL. Etiologic role of bacteria and intestinal function. In: Brown EG, Sweet AY, eds. Neonatal Necrotizing Enterocolitis. New York: Grune \& Stratton, 1980;69-100.

35. Feuerstein G, Hallenbeck JM. Prostaglandins, leukotrienes, and platelet-activating factor in shock. Annu Rev Pharmacol Toxicol 1987;27:301-313.

36. Bone RC. The pathogenesis of sepsis. Ann Intern Med 1991;115:457-469.

37. Benveniste J. Paf-acether, an ether phospho-lipid with biological activity. Prog Clin Biol Res 1988;282:73-85.

38. Hanahan DJ. Platelet activating factor: A biologically active phosphoglyceride. Annu Rev Biochem 1986;55:483509.

39. Handley DA. Platelet-activating factor as a mediator of endotoxin-related diseases. In: Handley DA, Saunders RN, Houlihan WJ, Tomesch JC, eds. Platelet-Activating Factor in Endotoxin and Immune Diseases. New York and Basel: Marcel Dekker, 1990;451-495.

40. Toth PD. The biological effects of PAF antagonists on endotoxemia. In: Handley DA, Saunders RN, Houlihan WJ , Tomesch J C, eds. Platelet-Activating Factor in Endotoxin and Immune Diseases. New York and Basel: Marcel Dekker, 1990;589-608.

41. Beutler B, Cerami A. Tumor necrosis, cachexia, shock, and inflammation: a common mediator. Annu Rev Biochem 1988;57:505-518.

42. Zanetti G, Heumann D, Gerain J, et al. Cytokine production after intravenous or peritoneal gram-negative bacterial challenge in mice. Comparative protective efficacy of antibodies to tumor necrosis factor-al pha and to lipopolysaccharide. J Immunol 1992;148:1890-1897.

43. Tracey KJ, Beutler B, Lowry SF, et al. Shock and tissue injury induced by recombinant human cachectin. Science 1986;234:470-474.

44. Tracey KJ, Fong Y, Hesse DG, et al. Anti-cachectin/TNF monoclonal antibodies prevent septic shock during lethal bacteraemia. Nature 1987;330:662-664.

45. Snyder F. Platelet-activating factor and related acetylated lipids as potent biologically active cellular mediators. Am J Physiol 1990;259:C697-C708.

46. Denizot Y, Dassa E, Benveniste J, et al. Paf-acether production by Escherichia coli. Biochem Biophys Res Commun 1989;161:939-943.

47. Sanchez-Crespo M, Alonso F, Inarrea $P$, et al. Vascular actions of synthetic PAF-acether (a synthetic plateletactivating factor) in the rat: Evidence for a platelet independent mechanism. Immunopharmacology 1982;4: 173-185.

48. Hsueh W, Gonzalez Crussi F, Arroyave J L, et al. Platelet activating factor-induced ischemic bowel necrosis: The effect of PAF antagonists. Eur J Pharmacol 1986;123:7983.

49. Stafforini DM, Elstad MR, Mclntyre TM, et al. Human macrophages secret platel et-activating factor acetylhydrolase. J Biol Chem 1990;265:9682-9687.

50. Tarbet EB, Stafforini DM, Elstad MR, et al. Liver cells secretethe plasma form of platelet-activating factor acetylhydrolase. J Biol Chem 1991;266:16667-16673. 
51. Tjoelker LW, Wilder C, Eberhardt C, et al. Anti-inflammatory properties of a platelet-activating factor acetylhydrolase. Nature 1995;374:549-553.

52. Zhang C, H sueh W, Caplan MS, Kelly A. Platelet activating factor-induced shock and intestinal necrosis in the rat: Role of endogenous platelet-activating factor and effect of saline infusion. Crit Care Med 1991;19:1067.

53. Schandene L, Vandenbussche P, Crusiaux A, et al. Differential effects of pentoxifylline on the production of tumour necrosis factor-alpha and interleukin- 6 by monocytes and T cells. Immunology 1992;76:30-34.

54. Giroir BP, J ohnson J H, Brown T, et al. The tissue distribution of tumor necrosis factor biosynthesis during endotoxemia. J Clin Invest 1992;90:693-698.

55. J aattela M. Biologic activities and mechanisms of action of tumor necrosis factor- $\alpha /$ cachectin. Lab Invest 1991;64: 724-742.

56. Vilcek J, LeeTH. Tumor necrosis factor. New insights into the molecular mechanisms of its multiple actions. J Biol Chem 1991;266:7313-7316.

57. Strieter RB, Kunkel SL, Bone RC. Role of tumor necrosis factor- $\alpha$ in disease states and inflammation. Crit Care Med 1993;21:S447-S463.

58. Camussi G, Bussolino F, Salvidio G, Baglioni C. Tumor necrosis factor/cachectin stimulates peritoneal macrophages, polymorphonuclear neutrophils, and vascular endothelial cells to synthesize and release plateletactivating factor. J Exp Med 1987;166:1390-1404.

59. ValoneFH, Epstein LB. Biphasic platelet-activating factor synthesis by human monocytes stimulated with I L-1-beta, tumor necrosis factor, or IFN-gamma. J Immunol 1988; 141:3945-3950.

60. Hsueh W, Sun X, Rioja LN, Gonzalez-Crussi F. The role of the complement system in shock and tissue injury induced by tumour necrosis factor and endotoxin. I mmunology 1990;70:309-314.

61. Sun X, Hsueh W. Platelet-activating factor produces shock, in vivo complement activation, and tissue injury in mice. J I mmunol 1991;147:509-514.

62. Huang L, Tan X, Crawford SE, Hsueh W. Plateletactivating factor and endotoxin induce tumour necrosis factor gene expression in rat intestine and liver. I mmunology 1994;83:65-69.

63. Collart MA, Baeuerle P, Vassalli P. Regulation of tumor necrosis factor alpha transcription in macrophages: Involvement of four $\kappa \mathrm{B}$-like motifs and of constitutive and inducible forms of NF-кB. Mol Cell Biol 1990;10:14891506.

64. BaeuerlePA. The inducibletranscription activator NF-kB: regulation by distinct protein subunits. Biochim Biophys Acta 1991;1072:63-80.

65. Tan X, Sun X, Gonzalez-Crussi FX, Gonzalez-Crussi F, $\mathrm{H}$ sueh W. PAF and TNf increase the precursor of NFkappa B p50 mRNA in mouse intestine: Quantitative analysis by competitive PCR. Biochim Biophys Acta 1994; 1215:157-162.

66. Deitch EA, Ma L, Ma WJ, et al. Inhibition of endotoxininduced bacterial translocation in mice. J Clin Invest 1989;84:36-42.

67. Sun X, Caplan MS, Liu Y, Hsueh W. Endotoxin resistant mice are protected from PAF-induced shock, tissue injury and death. Roles of TNF, complement activation and endogenous PAF production. Dig Dis Sci 1995;40:495502.

68. Sun X, MacKendrick W, Tien J, et al. Endogenous bacterial toxin is required for the injurious effect of PAF. Gastroenterology 1995;109:83-88.
69. Siren AL, Feuerstein G. Effects of PAF and BN 52021 on cardiac function and regional blood flow in conscious rats. Am J Physiol 1989;257:H 25-H 32.

70. Zhang $\mathrm{C}$, Hsueh W. PAF-induced bowel necrosis. Effects of vasodilators. Dig Dis Sci 1991;36:634-640.

71. Hsueh W, Gonzalez-Crussi F, Arroyave JL. Release of leukotriene $\mathrm{C}_{4}$ by isolated, perfused rat small intestine in responseto platelet-activating factor. J Clin I nvest 1986;78: 108-114.

72. Hsueh W, Gonzalez-Crussi F, Arroyave JL. Sequential release of leukotrienes and norepinephrine in rat bowel after platelet-activating factor. A mechanistic study of platel et-activating factor-induced bowel necrosis. Gastroenterology 1988;94:1412-1418.

73. Cueva J P, H sueh W. Role of oxygen derived free radicals in platelet activating factor induced bowel necrosis. Gut 1988;29:1207-1212.

74. Perdue $\mathrm{MH}$, Ramage JK, Burget $\mathrm{D}$, et al. Intestinal mucosal injury is associated with mast cell activation and leukotriene generation during Nippostrongylus-induced inflammation in the rat. Dig Dis Sci 1989;34:724-731.

75. Ninio E, Joly F, Hieblot $C$, et al. Bioxynthesis of pafacether. IX. Role for a phosphorylation-dependent activation of acetyltransferase in antigen-stimulated mouse mast cells. J I mmunol 1987;139:154-160.

76. Zimmerman GA, Whatley RE, M cl ntyre TM, Prescott SM. Production of platelet-activating factor, a biologically active lipid, by vascular endothelial cells. Am Rev Respir Dis 1987;136:204-207.

77. Feinmark SJ . The role of the endothelial cell in leukotriene biosynthesis. Am Rev Respir Dis 1992;146:S51-S55.

78. Sun X, Qu X, Huang W, et al. The role of leukocyte beta 2-integrin in PAF-induced shock and intestinal injury. Am J Physiol 1996;270:G184-G190.

79. Kubes P, Suzuki M, Granger DN. Platelet-activating factorinduced microvascular dysfunction: Role of adherent leukocytes. Am J Physiol 1990;258:G158-G163.

80. Kubes P, Arfors KE, Granger DN. Platelet-activating factorinduced mucosal dysfunction: Role of oxidants and granulocytes. AmJ Physiol 1991;260:G965-G971.

81. Sun X, Rozenfeld RA, Qu X, Huang W, Gonzalez-Crussi, Hsueh W. P-selectin-deficient mice are protected from PAF-induced shock, intestinal injury, and lethality. Am J Physiol 1997;273:G56-G61.

82. Keshav S, Lawson L, Chung LP, et al. Tumor necrosis factor mRNA localized to Paneth cells of normal murine intestinal epithelium by in situ hybridization. J Exp Med 1990;171:327-332.

83. Tan XD, Hsueh W, Gonzalez-Crussi F. Cellular localization of TNF-alpha transcripts in normal bowel and in necrotizing enterocolitis. TNF gene expression in Paneth cells, intestinal eosinophils and macrophages. Am J Pathol 1993;142:1858-1865.

84. Nevalainen TJ, Gronroos MJ, Kallajoki M. Expression of group II phospholipase $A_{2}$ in the human gastrointestinal tract. Lab Invest 1995;72:201-208.

85. Tan XD, Wang H, Gonzalez-Crussi FX, Chang H, GonzalezCrussi, H sueh W. Platelet-activating factor and endotoxin increase the enzyme activity and gene expression of type II phospholipase A2 in the rat intestine. J Immunol 1996;156:2985-2990.

86. Wiswell T, Robertson C, J ones T, et al. Necrotizing enterocolitis in full-term infants: A case-control study. Am J Dis Child 1988;142:532-535.

87. Leung M, Chau K, Hui $P$, et al. Necrotizing enterocolitis in neonates with symptomatic congential heart disease. J Pediatr 1988;113:1044-1046. 
88. Hackett GA, Campbell S, Gamsu H, et al. Doppler studies in the growth retarded fetus and prediction of neonatal necrotizing enterocolitis, haemorrhage, and neonatal morbidity. Br Med J 1987;294:13-16.

89. Czyrko C, Del Pin CA, O'Neill J A, et al. Maternal cocaine abuse and necrotizing enterocolitis: outcome and survival. J Pediatr Surg 1991;26:414-421.

90. Hansbrough F, Priebe CJ , Falterman KW, et al. Pathogenesis of early necrotizing enterocolitis in the hypoxic neonatal dog. Am J Surg 1983;145:169-175.

91. Caplan MS, Sun X-M, Hsueh W. Hypoxia causes ischemic bowel necrosis in rats: The role of platelet-activating factor (PAF-acether). Gastroenterology 1990;99:979-986.

92. MacKendrick W, Caplan M. Necrotizing enterocolitis: New thoughts about pathogenesis and potential treatments. Pediatr Clin North Am 1993;40:1047-1059.

93. MusemecheCA, KosloskeAM, Bartow SA, et al. Comparative effects of ischemia, bacteria and substrate on the pathogenesis of intestinal necrosis. J Pediatr Surg 1986;21: 536-537.

94. Caplan M, Kelly A, Hsueh W. Endotoxin and hypoxiainduced intestinal necrosis in rats: The role of platelet activating factor. Pediatr Res 1992;31:428-434.

95. Moncada S, Higgs EA. The L-arginine-nitric oxide pathway. New Engl J Med 1993;329:2002-2012.

96. Caplan M, Hedlund E, Hill N, MacKendrick W. The role of endogenous nitric oxide and platelet-activating factor in hypoxia-induced intestinal injury in rats. Gastroenterology 1994;106:346-352.

97. MacKendrick W, Caplan M, Hsueh W. Endogenous nitric oxide protects against platelet-activating factor-induced bowel injury in the rat. Pediatr Res 1993;34:222-228.

98. Topalian SL, Ziegler MM. Necrotizing enterocolitis: A review of animal models. J Surg Res 1984;37:320-366.

99. Crissinger KD. Animal models of necrotizing enterocolitis. J Pediatr Gastroenterol Nutr 1995;20:17-22.

100. Barlow B, Santulli TV, Heird WC, et al. An experimental study of acute neonatal enterocolitis-the importance of breast milk. J Pediatr Surg 1974;9:587-594.

101. Pitt J, Barlow B, Heird WC. Protection against experimental necrotizing enterocolitis by maternal milk. I. Role of milk leukocytes. Pediatr Res 1977;11:906-909.

102. Barlow B, Santulli TV. Importance of multiple episodes of hypoxia or cold stress on the development of enterocolitis in an animal model. Surgery 1975;77:687-690.

103. Caplan MS, Hedlund E, Adler L, Hsueh W. Role of asphyxia and feeding in a neonatal rat model of necrotizing enterocolitis. Pediatr Pathol 1994;14:1017-1028.

104. Caplan MS, Hedlund E, Adler L, Lickerman M, Hsueh W. The platelet-activating factor receptor antagonists WEB 2170 prevents neonatal necrotizing enterocolitis. J Pediatr Gastroenterol Nutr 1997;24:296-301.

105. Hu W, McNicholl IK, Choy PC, Man RYK. Partial agonist effect of the platelet-activating factor receptor antagonists, WE B 2086 and WEB 2170, in the rat perfused heart. Br J Pharmacol 1993;110:645-650.

106. Mukherjee AB, Miele L, Pattabiraman N. Phospholipase $A_{2}$ enzymes: Regulation and physiological role. Biochem Pharmacol 1994;48:1-10.

107. Vadas P, Pruzanski W. Induction of group II phospholipase $A_{2}$ expression and pathogenesis of the sepsis syndrome. Circ Shock 1993;39:160-167.

108. Caplan MS, Sun X-M, Hsueh W, Hageman J R. Role of platelet activating factor and tumor necrosis factor-al pha in neonatal necrotizing enterocolitis. J Pediatr 1990;116: 960-964.

109. MacKendrick W, Hill N, Hsueh W, Caplan M. Increase in plasma platelet-activating factor levels in enterally fed preterm infants. Biol Neonate 1993;64:89-95.

110. Amer MD, Caplan MS. Neonatal necrotizing enterocolitis increases platelet activating factor levels in the stool of newborn infants. Clin Res 1994;42:372A.

111. Farr RS, Wardlow ML, Cox CP, et al. Human serum acid-labile factor is an acylhydrolase that inactivates platelet-activating factor. Federation Proc 1983;42:31203122.

112. Caplan M, Hsueh W, Kelly A, Donovan M. Serum PAF acetylhydrolase increases during neonatal maturation. Prostaglandins 1990;39:705-714.

113. Lucas A, Cole TJ. Breast milk and neonatal necrotizing enterocolitis. Lancet 1990;336:1519-1523.

114. Furukawa M, Lee EL, J ohnston JM. Platelet-activating factor-induced ischemic bowel necrosis: The effect of platelet-activating factor acetylhydrolase. Pediatr Res 1993;34:237-241. 